THE GREAT BRITISH REBOOT 


\section{BY THE SAME AUTHOR}

The Guardian Guide to the UK's Top Companies, 1995

(Introduction)

Hanson: A Biography (with Roger Cowe)

Weinstock: The Life and Times of Britain's Premier Industrialist (with Roger Cowe)

The Crunch: The Scandal of Northern Rock and the Escalating Credit Crisis

The Great Pensions Robbery: How New Labour Betrayed Retirement

Britain for Sale: British Companies in Foreign Hands - The Hidden Threat to Our Economy

Bad Banks: Greed, Incompetence and the Next Global Crisis 

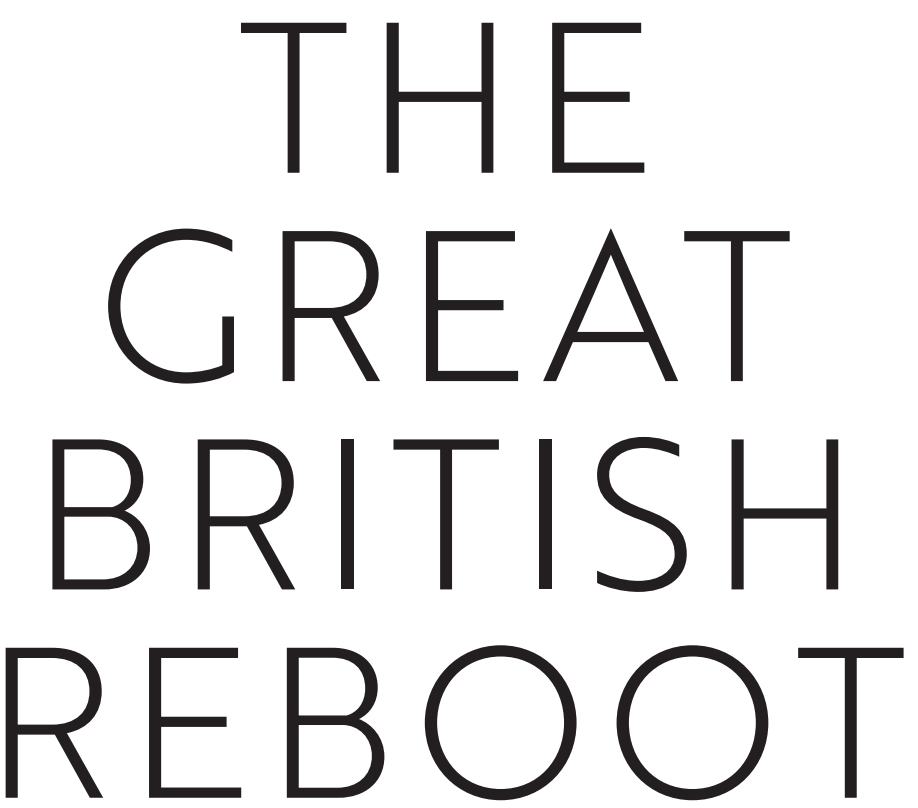

How the UK Can Thrive in a Turbulent World

ALEX BRUMMER

YALE UNIVERSITY PRESS

NEW HAVEN AND LONDON 
Copyright (C) 2020 Alex Brummer

All rights reserved. This book may not be reproduced in whole or in part, in any form (beyond that copying permitted by Sections 107 and 108 of the U.S.

Copyright Law and except by reviewers for the public press) without written permission from the publishers.

For information about this and other Yale University Press publications, please contact:

U.S. Office: sales.press@yale.edu yalebooks.com

Europe Office: sales@yaleup.co.uk yalebooks.co.uk

Set in Minion by IDSUK (DataConnection) Ltd

Printed in Great Britain by CPI Group (UK) Ltd, Croydon, CR0 4YY

Library of Congress Control Number: 2020943374

ISBN 978-0-300-24349-9

A catalogue record for this book is available from the British Library.

$\begin{array}{llllllllll}10 & 9 & 8 & 7 & 6 & 5 & 4 & 3 & 2 & 1\end{array}$ 
To my late parents Hilda and Michael Brummer of blessed memory 
